\title{
Paul Virilio, 2006. \\ CiUdad Pánico, \\ Buenos Aires, Editorial Libros del Zorzal. 140pp. \\ TRADUCCIÓN DE IAIR KON.
}

Vivir en las grandes ciudades, adaptarse a los rápidos cambios tecnológicos, modificar el tiempo de uno para adaptarse al transporte son algunas de las cosas de las que más nos quejamos los que vivimos en las ciudades y nadie mejor para realizar la crítica profunda y extensa en (cuanto a contenido) como el alumno de Merleau-Ponty: Paul Virilio.

En 140 páginas retrata una situación urbana que se expande por el mundo, y no pensando en que la tierra sufra una metamorfosis de pavimentación y grandes edificios, sino en que el pánico se universaliza.

Todo inicia entre París y Nantes, el contraste entre la paz y la guerra, a pesar de que el Nantes en el que Virilio creció haya sido un puerto de guerra, el exilio rural y el regreso a lo urbano, a sus calles, sus restaurantes, su gente, sus espacios abiertos, sus espacios cerrados, sus cementerios, sus museos y sus trayectos. La hipótesis de Virilio es que las nuevas ciudades terminarán por ser provocadoras de pánico, pues, al principio, al recorrer las ciudades, uno descubre y redescubre -después esto se convierte en un hábito- existe aquello que conocemos y aún así no cambiamos de ruta. París se convirtió en una metaciudad y los parisinos adaptaron un mapa mental que les permite transitar entre redes y, según Virilio, se podrían eliminar los mapas y los nombres de las calles y esto no perturbaría el paso diario de los viajantes.

Según Virilio los humanos necesitamos una ubicación espaciotemporal para no devenir en el vértigo, "en la pérdida del espacio real”, por esta razón el metro como circulación subterránea, oscura, y que son las vías ocultas de París, presenta plazas y espacios entre las estaciones; así los usuarios que viajan por debajo de la ciudad, se convierten en topos subterráneos, pero no se sienten ni perdidos ni desubicados. 
Controlar el principio y el fin de las rutas, calles, caminos y carreteras es poder manejar una frontera, sin embargo los viajes aéreos rompen con éstas, pues existe un control más allá del espacio físico: "Después de Dresde, pero sobre todo después de Hiroshima y Nagasaki, esa "aereopolítica” se ha convertido en una cosmopolítica del terror nuclear, con la estrategia anti-Ciudad que hasta hace poco subyacía 'al equilibrio del terror' entre el Este y el Oeste”. (Virilio, 2006: 25).

Para virilio al igual que para Baudrillard, la mayor exposición de este "terrorismo aéreo" es, por supuesto, la caída de las Torres Gemelas el 11 de septiembre de 2001: un avión de pasajeros se transforma en un arma, un incidente, una provocación, un ataque, una puesta en escena, es la ruptura de la geopolítica que se transforma en metropolítica de la estética, de los medios de comunicación y del terror social. La diferencia entre ambos autores es que Baudrillard desde la posmodernidad foucaultiana ve en la catástrofe el principio de algo, terrible o no, un cambio determinante, mientras que Virilio ve el accidente como algo que se debe de evitar, como lo terrible que ha traído la posmodernidad, justificación, que de alguna manera propone como el resto de su bibliografía, de la creación del museo del accidente, que pretende mostrar el terror para provocar evitarlo.

Por supuesto que dentro de los errores de la posmodernidad Virilio se pregunta ¿en qué se han convertido los medios de comunicación? Son mass media, constantemente trabajando, renovándose; una máquina productora de imágenes, patrones, modas, conductas, noticias, y finalmente son copartícipes del accidente. Parecemos seres fabricados, uniformados, iguales, globalizados, lo cual según Virilio conlleva al "accidente por el accidente", al arte por el arte, a la imagen por la imagen, a la palabra por la palabra, a la falta de necesidad de crear.

"Crear el accidente más que el acontecimiento...romper el encadenamiento de causalidad que caracteriza tan bien a la normalidad cotidiana; esa clase de expresionismo es buscada hoy en día universalmente, tanto por los 'terroristas' como por los 'artistas' y todos los activistas contemporáneos de la era de la globalización planetaria" (Virilio, 2006: 37). 
La palabra clave del terrorismo es la indiferencia. El principio de ésta, según Virilio, es la Primera Guerra Mundial como consecuencia de imágenes de trinchera cuyo olor aún hoy escapa de las fotografías, la aparición de tanques como un monstruo metálico imparable y los cuerpos escondidos por el lodo. Después de esto, la Segunda Guerra Mundial reafirma esta "indiferencia”, no sólo ante las bombas y los cuerpos de Hiroshima y Nagasaki transformados en sombras, también ante Auschwitz y sus hombres transformados en fantasmas antes de morir. Según Virilio, la indiferencia artística comenzó con el expresionismo, le siguió el surrealismo y ahora, es el terrorismo, acciones que bien podrían ser arte: "en ese sentido, y sólo en ese sentido, Karlheinz Stockhausen tenía razón al declarar el año pasado, a propósito del escenario terrorista de NuevaYork, que se trataba de 'la mayor obra de arte'.” (Virilio, 2006: 56).

Así comienza el mundo, o la humanidad en el mundo, a presentar síntomas del accidente del tiempo: la expansión de la localidad, de muchas localidades al mismo tiempo hace que se pierda la identidad de cada una y eso es la globalización, estamos por llegar a lo finito del mundo, al límite de la expansión y después de eso ¿estaremos dispuestos a la reducción?

En esta obsesión y ambición por expandirse surgen las Ciudades Pánico, las metrópolis “Ciudades Pánico que señalan, mejor que todas las teorías del caos, el hecho de que la catástrofe más grande del siglo XX ha sido la ciudad...” (Virilio, 2006: 94). El crecimiento no sólo es geográfico, sino energético, social, político, económico: para que Estados Unidos pueda encender todas sus luces se necesita que haya países que no enciendan ninguna y así se ha superado la geopolítica y se ha impuesto un desequilibrio terrorista, una amenaza externa y una interna que crece y se expande como pandillas, como grupos rebeldes, revolucionarios, mafias o antagonistas ante lo que hable de poder estatal.

El problema no es el espacio, es el espacio-tiempo y la aceleración y poco a poco se convierte en saturación por los espacios virtuales, hemos acelerado la realidad no la historia y el momento se ha vuelto inmediato.

El desierto visto como el horizonte al final será superado y llegaremos al desierto virtual: "al desierto convexo de un Universo en 
expansión se sobreañadirá el desierto cóncavo de la implosión de los puntos de vista." (Virilio, 2006: 104).

El libro es una propuesta de análisis sobre la llegada al accidente de los accidentes, una mirada a la situación: social, política, virtual, económica y geográfica que terminará siendo una metamirada para entender lo metasocial, la metapolítica, la metageografía y la metaeconomía. Es el comienzo, no de un debate público, sino de pensamientos e ideas internas que se sacuden el polvo y se discuten a ellas mismas. Es, finalmente, parte de la propuesta del Museo del accidente.

Natalia Stengel

Centro de Investigación Social Avanzada

natalia.stengel@cisav.org 